\title{
Peningkatan Fleksibilitas Sendi pada Pasien Stroke dengan Terapi Tali Temali
}

\author{
M. Jamaluddin ${ }^{1}$, Widiyaningsih², Zulfatun Nadhifah ${ }^{3}$ \\ 1,2,3Program Studi S1 Keperawatan STIKes Karya Husada Semarang \\ 1'tsabitha.afwani@gmail.com, ${ }^{2}$ widy.dianing@gmail.com*, ${ }^{3}$ zulfatunnadhifah209@gmail.com \\ * corresponding author
}

\begin{tabular}{l} 
Informasi artikel \\
Received: 06-10-2020 \\
Revised: 30-10-2020 \\
Accepted: $27-11-2020$ \\
\hline
\end{tabular}

fleksibilitas sendi, terapi tali temali, pasien stroke \begin{abstract}
ABSTRAK
Stroke merupakan gangguan peredaran darah di otak yang mengakibatkan terganggunya fungsi persyarafan di otak dan terjadi secara mendadak. Menurut WHO kejadian stroke mencapai 15 juta orang setiap tahun, dengan angka kematian mencapai hingga sepertiga dari seluruh kasus. Masalah yang dialami penderita stroke adalah gangguan gerak. Maka perlu dilakukan terapi non farmakologis berupa terapi tali temali. Latihan ini mampu meningkatkan elastisitas otot serta jaringan di area persendian karena dengan menggerakan sendi dapat melancarkan peredaran darah untuk mengurangi kekakuan fleksibilitas sendi. Tujuan penelitian ini untuk mengetahui peningkatan fleksibilitas sendi pada pasien stroke dengan terapi tali temali. Penelitian ini merupakan penelitian kuantitatif dengan Pre Experimental Design. Populasi penelitian ini adalah pasien post stroke non hemoragik di Poliklinik Saraf dengan jumlah sampel 20 orang. Pemilihan sampel menggunakan Purposive Sampling. Hasil analisa data menggunakan Uji Paired T-Test menunjukan $p$-value 0.000 atau $<0,05$ maka dapat disimpulkan ada pengaruh terapi tali temali terhadap fleksibilitas sendi. Kesimpulan: Ada pengaruh terapi tali temali terhadap fleksibilitas sendi pada pasien stroke.
\end{abstract}

Key word: joint flexibility, rigging therapy, stroke patients

\section{ABSTRACT}

Stroke is a disorder of nervous system function that occurs suddenly and is caused by circulatory disorders in the brain. WHO recruits about 15 million people suffer the first stroke each year, with one third of these cases or around 6.6 million can result in death. The problem that is often experienced by stroke sufferers is movement disorders. Therefore, it is necessary to do non-pharmacological therapy in the form of rigging therapy which is to increase the length and elasticity of the muscles and tissues around the joints because by moving the joints can accelerate circulation in the blood in order to reduce the stiffness of joint flexibility. Objective: To determine the effect of rigging therapy toward joint flexibility for stroke patients in Public Hospital of Ungaran Research method: Jenis penelitian ini adalah kuantitatif dengan Pre Experimental Design. Populasi penelitian ini adalah pasien penderita gejala post stroke non hemoragik di Poliklinik Saraf RSUD Ungaran dengan sampel sebanyak 20 orang. Teknik sampling pada penelitian ini adalah Purposive Sampling. Result: The normality test used the Sapiro Wilk Test results obtained before therapy 0.062 (>0.05) and obtained results after therapy 0.068 (>0.05). Statistical tests used the Paired T-Test show a p-value of 0.000 or $<0.05$, so it can be concluded that there was an effect of rigging therapy on joint flexibility. Conclusion: There was an effect of rigging therapy on joint flexibility in stroke patients at Public Hospital of Ungaran

\section{Pendahuluan}

Stroke merupakan defisit (gangguan) fungsi anggota tubuh terutama pada sistem persarafan yang dapat terjadi secara tiba- tiba dan bias juga disebabkan karena gangguan peredaran darah di otak. Kejadian stroke dapat juga terjadi akibat gangguan pada pembuluh darah yang ada di otak. 
Peredaran darah di otak bias mengalami gangguan yang di akibat karena terjadinya sumbatan pembuluh darah diotak atau terjadi karena pecahnya pembuluh darah yang ada di otak sehingga terjadi penurunan atau kekurangan suplai oksigen ke otak yang menyebabkan kematian pada sel-sel yang ada disaraf (neuron) (Rahayu, 2015). Menurut data yang dikeluarkan WHO (World Health Organization) 2016 secara keseluruhan bahwa stroke menduduki urutan kedua penyebab dari kematian, dan penyebab yang paling umum keenam yang dapat menimbulkan kecacatan (Pongantung, JMJ, \& Melchi, 2018) .Prevalensi angka kejadian stroke pada tahun 2013 di Indonesia berdasarkan umur $\geq 15$ tahun sebanyak 7\%. Sedangkan Prevalensi angka kejadian stroke pada tahun 2018 berdasarkan sebanyak 10,9\% (Kemenkes, 2018).

Prevalensi angka kejadian stroke khusunya di Provinsi Jawa Tengah sesuai data dari DINKES pada tahun 2017 bahwa jumlah stroke hemoragik (SH) sebanyak $35,3 \%$ dan stroke non hemoragik (SNH) sebanyak $64,7 \%$. Sedangkan jumlah kasus stroke hemoragik (SH) pada tahun 2017 terbanyak di Kab. Sukoharjo sebesar 14,9\% kasus, disusul Kab. Brebes sebesar 11\% kasus, sedangkan untuk urutan ketiga terdapat di Kota Surakarta yaitu sebesar 9\% kasus. Jumlah kasus stroke non hemoragik (SNH) pada tahun 2017 terbanyak di Kab. Brebes sebesar 16,4\% kasus, urutan kedua terdapat di Kab. Klaten sebesar 15,7\% kasus dan untuk urutan ketiga terdapat di Kab. Kebumen sebesar 8,2\% kasus (Dinkes, 2015)

Gangguan system syaraf yang terjadi pada penderita stroke dapat menimbulkan gejala-gejala yang khusus seperti: kelumpuhan anggota badan, gangguan ketika bicara termasuk pelo, terjadi ketidak seimbangan, perubahan kesadaran, bahkan sampai mengalami gangguan penglihatan (Bakara \& Warsito, 2016). Gangguan yang sering dirasakan oleh pasien stroke adalah gangguan ektremitas baik atas maupun bawah sehingga akan mengalami kesulitan saat beraktifitas hal itu terjadi karena mengalami gangguan otot dan keseimbangan gerak. Penderita stroke yang terlambat dalam menangani penderita atau tidak segera mendapatkan pertolongan yang tepat maka akan mengakibatkan terjadinya komplikasi yang lebik komplek, salah satunya adalah kontraktur. Hilang / kurangnya lingkup pergerakan sendi baik pasif ataupun aktif karena mengalami keterbatasan pada sendi yang dapat menyebabkan berbagai masalah diantaranya keterbatasan dalam rentang gerak sendi, hilangnya fungsi pada anggota gerak, gangguan melakukan perpindahan sesuai kemampuan anggota gerak, gangguan melakukan aktivitas sampai pada kasus kecacatan yang tidak dapat disembuhkan (Santoso, Bartiah, Khafidlotur, Permadhi, \& Argaditama, 2014) Fleksibilitas sendi dapat didefinisikan sebagai kemampuan untuk bergerak bebas dan efektif tanpa rasa sakit antar sendi dan tulang yang memungkinkan pergerakan maupun yang tidak bergerak satu sama lain (Asikin, 2016). Oleh sebab itu penanganan stroke membutuhkan tehnik dalam merehabilitasi dengan tujuan untuk mengurangi kecacatan, tindakan yang tepat agar dapat menjalani aktivitas secara normal yaitu dengan melakukan rehabilitasi. Rehabilitasi harus dimulai sedini mungkin secara cepat dan tepat waktu sehingga dapat membantu mengembalikan fungsi fisik yang lebih cepat dan optimal. Rehabilitasi juga dapat menghindari terjadinya kelemahan otot apabila tidak dilakukan latihan atau terapi setelah pasien mengalami stroke (Olviani, Mahdalena, \& Rahmawati, 2017)

Rehabilitasi non farmakologis dalam memobilisasi persendian selain ROM juga dapat diberikan dengan cara terapi tali temali. Terapi tali temali adalah konsep kegiatan yang bias dilakukan dengan cara bermain, yang sesuai prinsip pengembangan motorik halus yaitu dengan menggunakan. gerakan aktif untuk melatih fleksibilitas terhadap sendi (Lestari, 2017). Pada dasarnya tujuan dari dilakukannya mobilitas sendi untuk, meningkatnya kinerja otot,dan memperluas ruang gerak pada sendi dan untuk mengurangi kejadian cedera serta untuk merangsang nutrisi pada kartilago (Mujib \& Suprayitno, 2016)

Latihan tali temali merupakan bentuk latihan untuk meningkatkan pergerakan otot dan kelenturan sendi dan jaringan yang ada disekitar sendi karena dengan menggerakan sendi dapat melancarkan peredaran dalam darah. Terapi tali temali ini bisa dikatan aman karena tidak menimbulkan efek samping, tali temali ini merupakan latihan dasar untuk 
mempertahankan, memperbaiki, dan meningkatkan kemampuan untuk menggerakkan persendian secara normal dan lengkap untuk meningkatkan massa otot dan tonus otot (Utomo \& Arofah, 2015).

Sesuai dengan hasil studi pendahuluan pada tanggal 23 Agustus 2019 di Rumah Sakit Umum Daerah Ungaran terdapat penderita yang mengalami gejala post stroke non hemoragik pada tahun 2019 sebanyak 52. Dari populasi tersebut terdapat 20 pasien perempuanyang mengalami gejala post stroke non hemoragik. Dari hasil wawancara $40 \%$ orang penderita yang mengalami gangguan fleksibilitas sendi .

\section{Metode Penelitian}

Penelitian ini dengan menggunakan kuantitatif dengan desain penelitian pre experimental design one-group pretestposttest design bertujuan untuk menilai adanya pengaruh perlakuan terapi tali temali terhadap fleksibilitas sendi. Populasi dalam penelitian ini adalah penderita perempuan yang mengalami gejala post stroke non hemoragik di RSUD Ungaran sebanyak 52 penderita yang mengalami gejala post stroke non hemoragik. Teknik sampling dengan purposive sampling yaitu penetapan sampel sesuai dengan kriteria yang telah ditetapkan peneliti berjumlah 20 responden.

\section{Hasil dan pembahasan}

Tabel 1. Gambaran fleksibilitas sendi sebelum dan sesudah diberikan terapi tali temali selama 5 menit

\begin{tabular}{llllll}
\hline Statistik & $\mathrm{N}$ & Min. & Max. & Mean & SD \\
\hline Pre & 20 & 25 & 65 & 51.75 & 11.035 \\
\hline Post & 20 & 60 & 85 & 76.50 & 7.090 \\
\hline
\end{tabular}

Hasil penelitian menunjukkan bahwa rata-rata fleksibilitas sendi sebelum terapi tali temali adalah 51,75. Dan rata-rata fleksibilitas sendi sesudah terapi tali temali adalah 76,50. Hasil Uji normalitas didapatkan nilai $p$-value sebelum terapi tali temali 0,062 dan sesudah terapi tali temali 0,068 sehingga data disimpulkan berdistribusi normal ( $p$-value $>0.05$ ). Hasil penelitian dari 20 responden menunjukkan bahwa nilai fleksibilitas sendi sebelum diberikan terapi tali temali rata-rata sebesar 51,75 dengan luas fleksibilitas sendi tertinggi sebesar 65 dan luas fleksibilitas sendi terendah sebesar 25. Artinya nilai tersebut kurang dari nilai normal fleksibilitas sendi. Nilai normal fleksibilitas sendi untuk fleksi $80^{\circ}$ dan untuk ekstensi $70^{\circ}$. Fleksibilitas dapat didefinisikan sebagai kemampuan seseorang untuk melakukan gerakan secara bebas tanpa rasa sakit pada sendi atau kelompok sendi. Terapi tali temali bisa dilakukan pada pasien yang mengalami kontraksi otot aktif atau gerakan sendi pasif (Yudha, Adji, \& Widodo, 2019).

Angka kejadian dari fleksibilitas sendi pada responden post stroke rata-rata kurang normal dikarenakan kekakuan pada sendi. Kekakuan pada sendi bisa diakibatkan kurangnya pergerakan atau aktivitas fisik post stroke sehingga dapat mempengarui rentang gerak sendi dan dapat mengakibatkan penurunan massa otot. Penurunan massa otot akan berdampak pada kegiatan aktivitas sendi sehingga akan mengakibatkan kepekatan cairan sinovial dan menyebabkan kekakuan sendi, karena sinovium sebagai penghasil cairan sinovial yang membasahi atau melumasi permukaan sendi (Anita, Pongantung, Ada, \& Hingkam, 2018). Maka dari itu fleksibilitas sendi perlu dilatih, dengan melakukan latihan secara rutin dan teratur akan mengurangi kekakuan sendi dan dapat meningkatkan fleksibilitas sendi dengan baik (Chandra, 2017). Di dalam penelitian ini peneliti menggunakan waktu 8 kali dalam 2 minggu dan dilakukan sehari 2 kali pagi dan siang, selama 5 menit

Pasien pasca stroke bagian tangan, dalam melakukan latihan fleksibilitas ditujukan untuk meningkatkan kekakuan dan mobilitas sendi, serta untuk mencegah hilangnya atau berkurangnya lingkup gerak pada sendi atau jaringan lunak. Fleksibilitas dibutuhkan oleh sendi-sendi umumnya untuk dapat bergerak secara bebas tanpa disertai sakit (Pangemanan, Engka, \& Supit, 2012).

Hasil penelitian dari 20 responden menunjukkan bahwa nilai fleksibilitas sendi sesudah melakukan terapi tali temali ratarata sebesar 76,50 dengan luas fleksibilitas sendi tertinggi sebesar 85 dan luas fleksibilitas sendi terendah sebesar 60 . Artinya luas fleksibilitas sendi setelah melakukan terapi tali temali mengalami peningkatan dalam rentang normal.

Pelaksanaan terapi tali temali dapat dilakukan dengan bermain, sesuai prinsip bahwa terapi tali temali bias juga untuk motorik dengan menggunakan gerakan aktif untuk melatih fleksibilitas terhadap sendi (Lestari, 2017). Pemberian terapi tali 
temali merupakan terapi untuk memperluas derajat rentang gerak sendi terutama pada ekstremitas atas dengan tujuan untuk mencegah komplikasi. Penanganan pada pasien stroke dalam proses rehabilitasi dimulai secepat mungkin, karena semakin cepat proses penangananya akan semakin kecil penderita mengalami gangguan pergarakan. Pemberian terapi tali temali yang dilakukan secara rutin pada pasien pasca stroke akan mengembalikan fungsi gerak sendi (Anita, Pongantung, Ada, \& Hingkam, 2018).

Manfaat dari terapi temali terhadap fleksibilitas sendi pada pasien stroke yaitu meningkatkan stimulasi kemampuan motorik halus, memberikan rasa gembira pada penderita, meningkatkan kemampuan pergerakan ekstremitas dalam beraktivitas (Lestari, 2017). Kondisi responden setelah melakukan terapi merasa lebih rileks dan lebih tenang, keadaan otot seorang yang mengalami gangguan fleksibilitas sendi akan lebih kaku, tegang sehingga saraf simpatis menjadi aktif. Terapi tali temali sendiri untuk mempengaruhi fungsi dan manifestasi tubuh dan mempunyai dampak yang baik bagi kesehatan, dapat menenangkan pikiran sehingga tubuh menjadi lebih rileks. Perubahan yang terjadi selama terapi mempengaruhi kerja otot dan menstimulasi otot sehingga menyebabkan pergerakan.

Tabel 2. Pengaruh terapi tali temali terhadap fleksibilitas sendi

\begin{tabular}{ccc}
\hline $\begin{array}{c}\text { Fleksibilitas } \\
\text { sendi }\end{array}$ & Mean & P-value \\
\hline Pre & 51,75 & 0,000 \\
Post & 76,5 & \\
\hline
\end{tabular}

Berdasarkan tabel 2 menunjukkan ada pengaruh terapi tali temali terhadap fleksibilitas sendi pada pasien stroke karena didapatkan hasil dengan $p$-value < $0.05(0,000)$. Berdasarkan analisa bivariat dihasilkan nilai $\mathrm{p}$ value $<0,05$ maka $\mathrm{H}_{0}$ ditolak atau $\mathrm{H}_{\mathrm{a}}$ diterima artinya terdapat

\section{Kesimpulan}

Ada pengaruh terapi tali temali terhadap fleksibilitas sendi pada pasien stroke sesudah melakukan terapi.

\section{Daftar Pustaka}

Anita, F., Pongantung, H., Ada, P. V., \& Hingkam, V. (2018). Pengaruh Latihan pengaruh terapi tali temali terhadap fleksibilitas sendi pada pasien stroke.

Terapi tali temali merupakan suatu konsep yang biasa dilakukan dengan tehnik bermain karena bertujuan untuk melatik motorik dengan menggunakan gerakan aktif dan untuk melatih fleksibilitas sendi. Terapi tali temali lebih baik jika menggunakan tali dengan bahan polyester contohnya tali pramuka karena mudah didapat, teksturnya lentur, tidak licin, dan tahan lama serta tidak menimbulkan efek samping luka pada tangan (Lestari, 2017). Durasi terapi tali temali juga mempengaruhi respon, terapi tali temali dilakukan selama 5 menit (Anita, Pongantung, Ada, \& Hingkam, 2018).

Terapi tali temali dilakukan untuk mencegah terjadinya kecacatan secara permanen sehingga pelaksanaan terapi tali temali pasien pasca stroke dapat juga di lakukan di rumah sakit untuk membantu menurunkan tingkat ketergantungan pasien pada keluarga, untuk mencegah komplikasi sebaiknya latihan tali temali pada pasien stroke sebaiknya dilakukan beberapa kali dalam sehari. Karena semakin cepat proses rehabilitasi dimulai semakin kecil kerusakan yang akan terjadi (Sulianti \& Sahroni, 2017). Sehingga latihan terapi tali temali dapat dilakukan saat pasien berada di rumah dan dengan rutin melakukan terapi tali temali dapat meningkatkan mobilitas sendi sehingga terjadinya komplikasi akan berkurang (Rahayu, 2015). Melatih pergerakan sendi sangat penting untuk mengoptimalkan ruang pergerakan sendi, dan untuk meningkatnya kinerja otot serta untuk mengurangi resiko terjadinya cedera mobilitas sendi juga dapat memperbaiki nutrisi pada kartilago atau tulang rawan (Hannan et al., 2019). Terapi tali temali dilakukan untuk latihan pergerakan fisik dapat meningkatkan elastisitas otot dan jaringan yang ada disekitar sendi, karena dengan menggerakan sendi secara ruti dapat melancarkan peredaran darah dalam tubuh (Utomo \& Arofah, 2015).

Range Of Motion Terhadap Rentang Gerak Sendi Ekstremitas Atas Pada Pasien Pasca Stroke Di Makassar. Journal of islamic nursing , 3 (1), 97-105.

Asikin, M. (2016). Keperawatan Medikal Bedah : Sistem Muskuloskeletal. Jakarta: Erlangga.

Bakara, D. M., \& Warsito, S. (2016). Latihan Range Of Motion (Rom) Pasif Terhadap 
Rentang Sendi Pasien Pasca Stroke. Idea Nursing Journal , VII (2), 12-18.

Chandra, C. (2017). Pengaruh Fleksibilitas Tubuh Terhadap Keterampilan Senam Lantai Pada Mahasiswa FIO UNJ 2017. Prosiding Seminar dan Lokakarya Fakultas Ilmu Keolahragaan Universitas Negeri Jakarta, 2, pp. 46-49. Jakarta.

Dinkes, J. (2015). Profil Kesehatan Provinsi Jawa Tengah 2015. Semarang: Dinas Kesehatan Provinsi Jawa tengah.

Kemenkes. (2018). Laporan hasil Riset Kesehatan Dasar (RISKESDAS) Nasional. Kementerian Kesehatan Badan Penelitian dan Pengembangan Kesehatan. Jakarta: Kementrian Kesehatan RI.

Lestari, S. (2017). Meningkatkan Keterampilan Motorik Halus Melalui Kegiatan Tali Temali Pada Kelompok B Di TK Aba Dekso, Banjararum, Kalibawang, Kulon Progo. Jurnal Pendidikan Anak Usia Dini , VI (3), 271-281.

Hannan, M., Suprayitno, E., \& Yuliyana, H. (2019). Pengaruh Terapi Kompres Hangat Terhadap Penurunan Nyeri Sendi Osteoarthritis Pada Lansia Di Posyandu Lansia Puskesmas pandian Sumenep. Wiraraja Medika, 9(1), 1-10.

Mujib, M., \& Suprayitno, E. (2016). Pengaruh latihan range of motion (rom) terhadap perubahan skala nyeri pada lansia dengan osteoartritis di posyandu lansia desa kalianget timur kecamatan kalianget kabupaten sumenep. Journal Of Health Science (Jurnal Ilmu Kesehatan), 1(2), 55-62.

Olviani, Y., Mahdalena, M., \& Rahmawati, I. (2017). Pengaruh Latihan Range of Motion (Rom) Aktif-Asistif (Spherical Grip) Terhadap Peningkatan Kekuatan Otot Ekstremitas Atas Pada Pasien Stroke Di Ruang Rawat Inap Penyakit Syaraf (Seruni) RSUD Ulin Banjarmasin. Dinamika Kesehatan: Jurnal Kebidanan dan Keperawatan , 8 (1), 250-257.
Pangemanan, D. H., Engka, J. N., \& Supit, S. (2012). Gambaran Kekuatan Otot Dan Fleksibilitas Sendi Ekstremitas Atas Dan Ekstremitas Bawah Pada Siswa/I Smkn 3 Manado. Jurnal Biomedik: JBM , 4 (3), S109-118.

Pongantung, H., JMJ, S. A., \& Melchi, S. D. (2018). Pengaruh Range Of Motion Pada Ekstremitas Bawah Terhadap Keseimbangan Berjalan Pada Pasien Pasca Stroke Di Rs. Stella Maris Makassar. Jurnal Ilmiah Kesehatan Diagnosis , 12 (3), 271-276.

Rahayu, K. I. (2015). Pengaruh Pemberian Latihan Range Of Motion (ROM) Terhadap Kemampuan Motorik Pada Pasien Post Stroke Di Rsud Gambiran. Jurnal Keperawatan , 6 (2), 102-107.

Santoso, E. J., Bartiah, M., Khafidlotur, M., Permadhi, R. A., \& Argaditama, R. (2014). Pengaruh Latihan Lateral Prehension Grip Terhadap Peningkatan Luas Gerak Sendi (LGS) Jari Tangan Pada Pasien Stroke Di SMC RS Telogorejo Semarang. Semarang. Jurnal Ilmu Keperawatan dan Kebidanan (JIKK) , 6, 1-10.

Sulianti, A., \& Sahroni, D. (2017). Terapi Biopsikologi Di Rumah Untuk Meningkatkan Kekuatan Motorik Pasca Stroke Ulangan. Jurnal Biodjati , 2 (2), 126-137.

Utomo, A., \& Arofah, N. I. (2015). Tingkat Keberhasilan Theraband Therapy Dalam Meningkatkan Range Of Movement (Rom) Pasca Cedera Pergelangan Tangan Pada Tim Ukm Softball Universitas Negeri Yogyakarta. Medikora: Jurnal Ilmiah Kesehatan Olahraga , 14 (1), 1-13.

Yudha, F. G., Adji, R. S., \& Widodo, S. (2019). Pengaruh Aktivitas Joging Terhadap Fleksibilitas Articulatio Coxae. Jurnal Kedokteran Diponegoro , 8(1), 191-202. 